Article citation info:

CIEŚLIŃSKI, J.T., KRZYŻAK, J., KROPIWNICKI, J. et al. Experiments on compression ignition engine powered by nano-fuels. Combustion Engines. 2022, 188(1), 55-59. https://doi.org/10.19206/CE-142281

Janusz T. CIEŚLIŃSKI (1)

Jan KRZYŻAK

Jacek KROPIWNICKI (C)

Zbigniew KNEBA (D)

\title{
Experiments on compression ignition engine powered by nano-fuels
}

ARTICLE INFO

Received: 15 July 2021

Revised: 14 September 2021

Accepted: 14 September 2021

Available online: 16 September 2021
The use of nanoparticles in fuels provides new opportunities for modification of fuel properties, which may affect the operational parameters of engines, in particular the efficiency and fuel consumption. The paper presents comparison of compression ignition engine performance fuelled with neat diesel and nano-diesel. Alumina $\left(\mathrm{Al}_{2} \mathrm{O}_{3}\right)$ was used as nanoparticles. Surface-active substances, including Span 80 surfactant, as well as water admixture were used to improve the stability of the produced fuel. Measurements of the thermal conductivity and dynamic viscosity of the produced mixtures were conducted. In this study was used naturally aspirated water cooled, four-stroke diesel engine. Addition of $\mathrm{Al}_{2} \mathrm{O}_{3}$ nanoparticles result in $4 \%$ reduced fuel consumption, addition of $\mathrm{TiO}_{2}$ nanoparticles result in $10 \%$ reduced fuel consumption with respect to neat diesel fuel.

Key words: nano-fuels, compression ignition engine, fuel consumption, turbidity, fuel optical transparency

This is an open access article under the CC BY license (http://creativecommons.org/licenses/BY/4.0/)

\section{Introduction}

Nanofluid is a suspension consisted of the base liquid and metallic or non-metallic nanoparticles with sizes significantly smaller than $100 \mathrm{~nm}$. Despite the small share of nanoparticles - from a few ppm to several percent of volume or mass concentration, the nanofluids exhibit completely different thermophysical properties than the socalled base fluids.

In recent years, attempts have been made to produce engine fuels that are mixtures of liquid fuels and nanoparticles. The studies were primarily concerned with dieselbased nanofuels although some attempt were made to fabricate and test the gasoline based nanofuels. Comprehensive state-of-the-art reviews regarding nanofuels have been presented in the literature [1-3]. Several fundamental aspects connected with nanofuels have been studied. First of all thermophysical properties of the nanofuels. It is well established that addition of nanoparticles to the base fluid increases both the thermal conductivity and viscosity $[4,5]$. Viscosity increase causes poor atomization, dispersion and lower penetration of fuel which is responsible for poor mixing of air and fuel inside the cylinder [6]. In order to utilize the potential benefits of nanoparticle addition it is essential to produce stable and homogeneous nanofuels. It is known fact that poorly stabilized nanofuels always deteriorates the overall operating characteristics of an engine. Moreover, aggregation of nanoparticles not only causes the problem of settlement of particles but also increases the chances of clogging of fuel injection system. Two methods are promising in stabilization of nanofuels: application of surfactants [7] and emulsification of fuels [8, 9]. Another very carefully studied aspects are ignition and combustion of nanofuels [10]. Published studies revealed that addition of nanoparticle to fuel acts as combustion catalyst and improves combustion behavior [11]. It was found that burning rates of hydrogen with diesel fuel in the presence of aqueous aluminum were quite high. The reason can be attributed due to small aluminum particle size and high oxidation rates which provides larger contact surface areas for decomposition of more hydrogen from water $[12,13]$. It was pointed out that metal particles are always covered with a natural oxide layer, which limits the oxidation process at low temperatures and also have a marked influence on ignition and combustion process [14]. For instance, it was shown that the presence of nanoboron particles in the fuel reduces the ignition delay which could be responsible for more complete combustion of hydrocarbon fuels [15]. Physics of nanofuel droplet combustion is investigated as well [11]. It was established that nanoscale suspension are permeable porous and uniformly distributed structure which is responsible for the early occurrence of micro explosion phenomenon [16]. Evaporation characteristics of nanodroplets was studied as well [17]. It is almost common consensus that metal nanoscale additives enhanced catalytic activity during combustion process and as a consequence leads to the better engine characteristics defined by such parameters as brake power (BP), brake thermal efficiency (BTE) and brake specific fuel consumption (BSFC). Literature data indicate slightly higher engine brake power [18, 19]. Experimental studies conducted with metallic, metal oxides and carbon nanotubes as additives to diesel fuel show higher brake thermal efficiency [20, 21]. Finally, addition of nanoparticles to diesel fuel results in lower engine brake specific fuel consumption [9, 22, 23]. It is necessary to stress, that the enhancement of BP and BTE or reduction of BSFC were observed up to a certain load of nanoparticles. The better performance is attributed to high surface area of nanoparticles which provides better heat transfer rates and further accelerates the combustion process provides fast oxidation, which promotes combustion reactions. Further it was observed that up to certain rpm value, there exist a linear relationship between brake power output and the amount of nanoparticle concentration in liquid fuels. Proper selection of type of nanoparticle with accurate concentration in liquid fuels should essentially be required for optimizing the engine performance parameters. Research studies report that addition of nanoparticles to diesel fuel results in significant decrease of exhaust gas emission and soot emissions of a diesel engine [24, 25]. The emission reduction level is directly related to the type 
and concentration of nanoparticles. It was known that $\mathrm{CO}$ emission mainly depends on equivalent air fuel ratio, though diesel engines generally operates with lean air fuel mixtures. It was shown that addition of nanoparticles to diesel fuel decreases $\mathrm{CO}$ emission up to a certain load limit $[26,27]$ and possible explanation of this phenomenon is that metal oxide nanoparticles during combustion behave as oxygen donating catalyst which augments the oxidation rate of $\mathrm{CO}$. The combustion in $\mathrm{CI}$ engine is connected with $\mathrm{NO}_{\mathrm{x}}$ emission, that depends upon number of factors, but first of all combustion temperature. It has been established that addition of nanoparticles to diesel fuel reduces $\mathrm{NO}_{\mathrm{x}}$ emissions significantly $[22,28]$. Possible explanation of this fact is the increased chemical reactivity of nanofluid that reduces the ignition delay period that would result in low peak combustion temperatures and low peak cylinder pressures which further reduces the $\mathrm{NO}_{\mathrm{x}}$ emission [27]. Experimental studies show that addition of nanoparticles to diesel fuel accelerates the flame propagation inside the cylinder, which lowers the carbon activation temperature and promotes more complete combustion (because nanoparticles act as oxidizing catalyst). These factors mainly inhibit the hydrocarbon emissions [29]. Lower smoke emission was observed by many authors due to higher evaporation rate and reduced ignition delay of nanofuels $[9,28,30]$.

As it was stated in $[3,31,32]$ limited experimental studies have been performed on diesel engine to investigate the engine performance parameters using nanofluid fuels and present paper supplements the data in the relevant literature.

Alumina $\left(\mathrm{Al}_{2} \mathrm{O}_{3}\right)$ was used as nanoparticles. Surfaceactive substances, including Span 80 surfactant, as well as water admixture were used to improve the stability of the produced fuel. Measurements of the thermal conductivity and dynamic viscosity of the produced mixtures were conducted.

\section{Experiment}

\subsection{Experimental stand}

Figure 1 shows scheme of the used experimental stand, to investigate engine characteristic. In this study was used naturally aspirated, water cooled, four-stroke diesel engine, technical details of engine is given in Table 1.

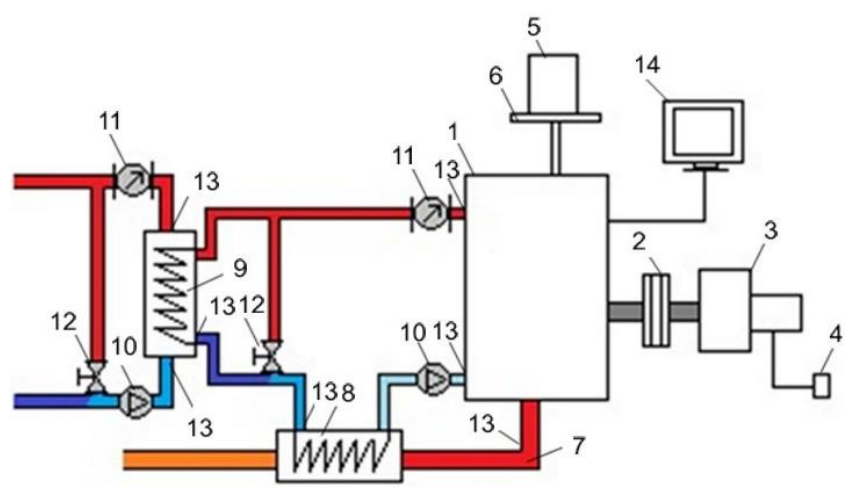

Fig. 1. Schematic diagram of experimental stand: 1 - engine, 2 - coupling, 3 - non-synchronous electric generator, 4 - electricity meter, 5 - fuel tank,

6 - scale, 7 - exhaust line, 8 - heat exchanger, 9 - cooler, 10 - pump, 11 flow meter, 12 - valve, 13 - thermocouples, 14 - computer
The fuel was supplied by a mechanically controlled injection system from a tank, in which diesel fuel mixed with nanoparticles in appropriate proportions was stored. The internal combustion engine powered a generator which allowed the engine to be loaded at a constant rotational speed. Due to the mechanical load control system used, it was not possible to achieve full repeatability of the load for the three tested fuel types at one of the operating points ( 8 $\mathrm{kW})$. The resulting discrepancies in the load settings did not, however, noticeably affect the characteristics of the analysed engine operating parameters.

Table 1. Test engine specification

\begin{tabular}{|l|c|}
\hline Test engine/type & Andoria S320 \\
\hline Number of cylinder & 1 \\
\hline Bore & $120 \mathrm{~mm}$ \\
\hline Stroke & $160 \mathrm{~mm}$ \\
\hline Engine volume & $1810 \mathrm{~cm}^{3}$ \\
\hline Compression ratio & $17: 1$ \\
\hline BSFC & $258 \mathrm{~g} / \mathrm{kWh}$ \\
\hline Power & $13.2 \mathrm{~kW}$ \\
\hline Max torque & $84.4 \mathrm{Nm}$ \\
\hline Rotational speed & $1500 \mathrm{rev} / \mathrm{min}$ \\
\hline
\end{tabular}

\subsection{Preparation and characterization of the tested nanofluids}

Nanofuels were prepared by direct mixing and ultrasonification. Two types of nanoparticles were used in the research: $\mathrm{Al}_{2} \mathrm{O}_{3}$ and $\mathrm{TiO}_{2}$. Nanoparticles were supplied from SigmaAldrich, size below $50 \mathrm{~nm}$. Nanoparticles suspended in base fluid result in changes in optical properties. Figure 2 presents change in optical transparency in nanofuel $\mathrm{Al}_{2} \mathrm{O}_{3} 50$ ppm compared to neat diesel fuel. On the left show neat diesel fuel, letters behind sample are sharp, on the right show nanofuel consist of diesel fuel $-\mathrm{Al}_{2} \mathrm{O}_{3} 50$ ppm mass concentration. Sample on the right is cloudy and letters are fuzzy.

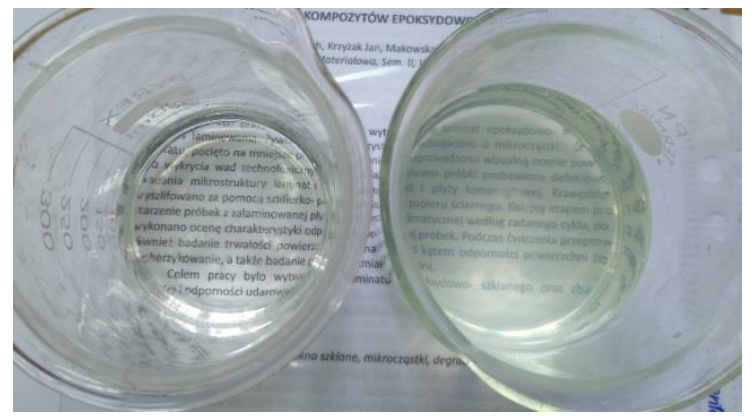

Fig. 2. Comparison optical transparency, a) neat diesel fuel b) nanofuel $\mathrm{Al}_{2} \mathrm{O}_{3} 50$ ppm, turbidity $\sim 30 \mathrm{NTU}$

As an example illustrating the influence of the fuel preparation method on its properties, the results of nonofuel $\mathrm{Al}_{2} \mathrm{O}_{3}$ tests are presented in Fig. 3 Turbidity value was measured by infrared Turbidimeter Al250T-IR. Figure 3 presents variation of nanofuel turbidity with respect to sedimentation time, for different preparation methods. Turbidity changes could be described by two slope curves, in first period after preparation turbidity decrease rapidly, after three days turbidity decrease slowly. The results show 
that method of preparation greatly influences the turbidity value. Direct mixing resulted in the lowest value of turbidity, only small part of particles was suspended in diesel fuel. Ultrasonification and combination of ultrasonification before direct mixing give comparable results, application direct mixing after ultrasonification result in slight increase of turbidity value. Combination of direct mixing before ultrasonification result in the highest turbidity value. The research did not include the measurement of the viscosity of fuels due to the lack of availability of measuring equipment adapted to the research in this area of nanofuels.

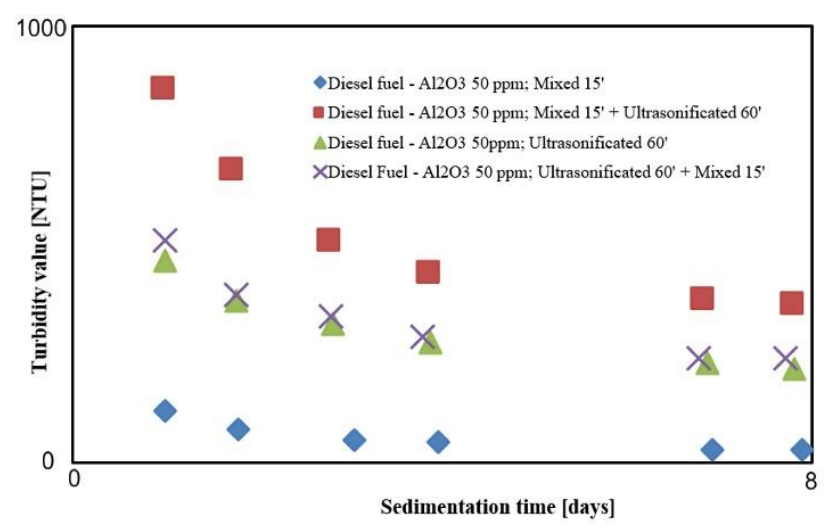

Fig. 3. Variation of nanofuel turbidity value with respect to sedimentation time for different preparation methods

\section{Results}

Figure 4 presents effect of nanoparticles on fuel consumption. Fuel consumption increases with the power increase The points are fitted into line, therefore linear approximation allow estimate effect nanoadditives on fuel consumption. Linear approximation curves are almost parallel, therefore comparing value of shifts between curves allow estimate changes in fuel consumption. Addition of $\mathrm{Al}_{2} \mathrm{O}_{3}$ nanoparticles result in $4 \%$ reduced fuel consumption, addition of $\mathrm{TiO}_{2}$ nanoparticles result in $10 \%$ reduced fuel consumption with respect to neat diesel fuel.

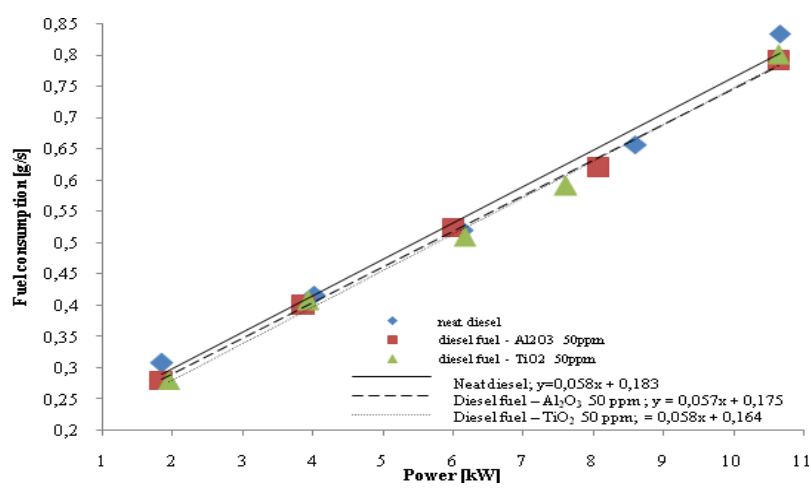

Fig. 4. The effect of nanoparticles on fuel consumption

The Figure 5 present effect of nanoparticles on brake specific fuel consumption. Brake specific fuel consumption decreases withe the power increase, values of BSFC are approaching to the value BSFC from engine specification Table1. In maximum power point, diesel fuel obtain BSFC
$=281 \mathrm{~g} / \mathrm{kWh}$, nanodiesel $\mathrm{Al}_{2} \mathrm{O}_{3}$ reduced about $4.9 \%$ BSFC to $267 \mathrm{~g} / \mathrm{kWh}$ with respect to neat diesel, nanodiesel $\mathrm{TiO}_{2}$ reduced about $3.9 \% \mathrm{BSFC}$ to $270 \mathrm{~g} / \mathrm{kWh}$ with respect to neat diesel.

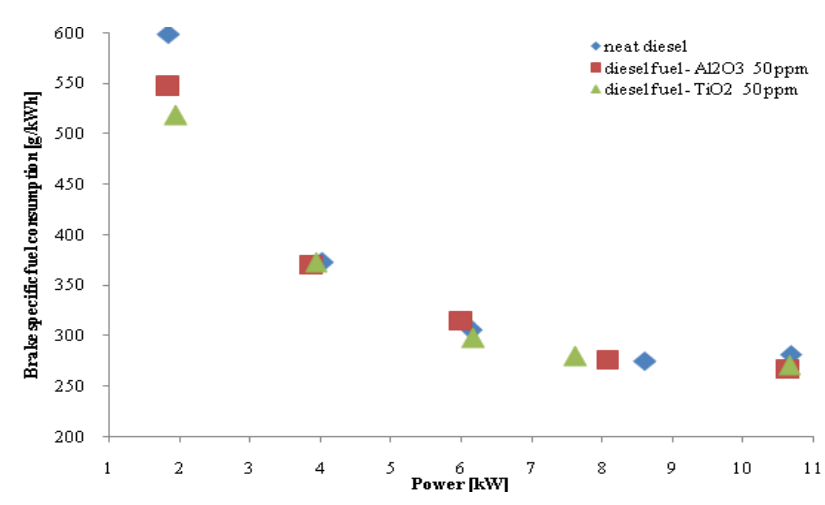

Fig. 5. Effect of nanoparticles on brake specific fuel consumption

Figure 6 presents effect nanoparticles on exhaust gas temperature. Exhaust gas temperature increase with the power increase. The points are fitted into line. There are no noticable changes in exhaust gas temperature after addition nanoparticles.

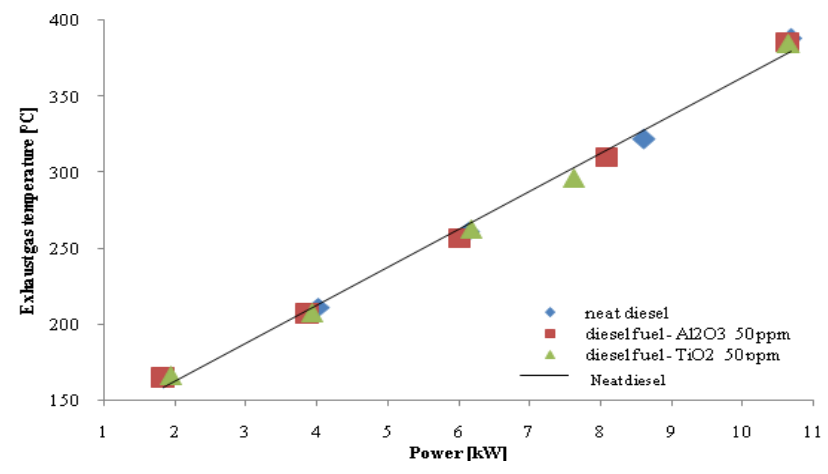

Fig. 6. Effect of nanoparticles on exhaust gas temperature

\section{Conclusions}

The use of nanoparticles as additives to diesel fuel may, according to the reported research results, bring a noticeable change in the course of the combustion process, mainly by modifying the thermal conductivity of the fuel. The tests carried out with the use of two types of nanofuels and net diesel oil as the reference fuel, allowed to conclude that the use of even small amounts of additives modifies the combustion process, leading to changes in the operational parameters of the engine. Nanoaddtives reduced fuel consumption, nanofuel $-\mathrm{Al}_{2} \mathrm{O}_{3} 50 \mathrm{ppm}$ reduced fuel consumption about $4 \%$, nanofuel $-\mathrm{TiO}_{2} 50 \mathrm{ppm}$ reduced fuel consumption about $10 \%$. It is worth noting that the change in fuel consumption is several orders greater than the change in fuel density resulting from the use of nanoparticles. There are not observed changes in the exhaust gas temperature after addition of nanoparticles. 


\section{Bibliography}

[1] SHAAFI, T., SAIRAM, K., GOPINATH, A. et al. Effect of dispersion of various nanoadditives on the performance and emission characteristics of a CI engine fuelled with diesel, biodiesel and blends - a review. Renewable and Sustainable Energy Reviews. 2015, 49, 563-573.

https://doi.org/10.1016/j.rser.2015.04.086

[2] KHOND, V.W., KRIPLANI, V.M. Effect of nanofluid additives on performances and emissions of emulsified diesel and biodiesel fueled stationary CI engine: a comprehensive review. Renewable and Sustainable Energy Reviews. 2016, 59, 1338-1348

https://doi.org/10.1016/j.rser.2016.01.051

[3] SAXENA, V., KUMAR, N., SAXENA, V.K. A comprehensive review on combustion and stability aspects of metal nanoparticles and its additive effect on diesel and biodiesel fuelled C.I. engine. Renewable and Sustainable Energy Reviews. 2017, 70, 563-588.

https://doi.org/10.1016/j.rser.2016.11.067

[4] CIEŚLIŃSKI, J.T., KRYGIER, K., SMOLEŃ, S. Measurement of temperature-dependent viscosity and thermal conductivity of alumina and titania thermal oil nanofluids. Archives of Thermodynamics. 2015, 36(4), 35-47. https://doi.org/10.1515/aoter-2015-0031

[5] CIEŚLIŃSKI, J.T. Wpływ nanocząstek na własności paliw silnikowych. XXIII Zjazd Termodynamików. Abstracts. 2017, 69-70.

[6] VAIRAMUTHU, G., SUNDARAPANDIAN, S., KAILASANATHAN, C. et al. Experimental investigations on the effects of cerium oxide nanoparticle on Calophyllum inophyllum (PUNNAI) biodiesel blended with diesel fuel in DI diesel engine modified by nozzle geometry. Journal of the Energy Institute. 2015, 5, 1-5.

https://doi.org/10.1016/j.joei.2015.05.005

[7] METHA, R.N., MORE, U., MALEK, N. et al. Study of stability and thermodynamic properties of water-in-diesel nanoemulsion fuels with nano-Al additive. Applied Nanoscience. 2015, 5, 891-900.

https://doi.org/10.1007/s13204-014-0385-3

[8] YANG, W.M. Impact of emulsion fuel with nano-organic additives on the performance of diesel engine. Applied Energy. 2013, 112, 1206-1212.

https://doi.org/10.1016/j.apenergy.2013.02.027

[9] BASHA, J.S., ANAND, R.B. Performance, emission and combustion characteristics of a diesel engine using Carbon Nanotubes blended Jatropha Methyl Ester Emulsions. Alexandria Engineering Journal. 2014, 53, 259-273.

https://doi.org/10.1016/j.aej.2014.04.001

[10] SHAAFI, T., VELRAJ, R. Influence of alumina nanoparticles, ethanol and isopropanol blend as additive with dieselsoybean biodiesel blend fuel: combustion, engine performance and emissions. Renewable Energy. 2015, 80, 655663. https://doi.org/10.1016/j.renene.2015.02.042

[11] MEHTA, R.N., CHAKRABORTY, M., PARIKH, P.A. Nanofuels: combustion, engine performance and emissions. Fuel. 2014, 120, 91-97.

https://doi.org/10.1016/j.fuel.2013.12.008

[12] KAO, M.J., TING, C.C., LIN, B.F. et al. Aqueous aluminum nano fluid combustion in diesel fuel. Journal of Testing and Evaluation. 2008, 36, 186-190. https://doi.org/10.1520/JTE100579

[13] MEHTA, R.N., CHAKRABORTY, M., PARIKH, P.A. Impact of hydrogen generated by splitting water with nanosilicon and nano-aluminum on diesel engine performance. International Journal of Hydrogen Energy. 2014, 39, 80988105. https://doi.org/10.1016/j.ijhydene.2014.03.149
[14] WEN, D. Nanofuel as potential secondary energy carrier. Energy \& Environmental Science. 2010, 3, 591-600. https://doi.org/10.1039/B906384F

[15] KARMAKAR, S., HANBERRY, J., DOOLEY, K.M. et al. Pre and post-combustion characteristics of boron nanoparticles in an ethanol spray flame. International Journal of Energetic Materials and Chemical Propulsion. 2011, 10, 1-17. https://doi.org/10.1615/IntJEnergeticMaterialsChemProp.20 12002669

[16] GAN, Y., QIAO, L. Combustion characteristics of fuel droplets with addition of nano and micron-sized aluminum particles. Combustion and Flame. 2010, 158, 354-368. https://doi.org/10.1016/j.combustflame.2010.09.005

[17] GAN, Y., LIM, Y.S., QIAO, L. Combustion of nanofluid fuels with the addition of boron and iron particles at dilute and dense concentrations. Combustion and Flame. 2012, 159, $1732-1740$. https://doi.org/10.1016/j.combustflame.2011.12.008

[18] NADEEM, M., RANGKUTI, C., ANAUR, K. et al. Diesel engine performance and emission evaluation using emulsified fuels stabilized by conventional and gemini surfactants. Fuel. 2006, 85, 2111-2119. https://doi.org/10.1016/j.fuel.2006.03.013

[19] GUMUS, S., OZCAN, H., OZBEY, M. et al. Aluminum oxide and copper oxide nanodiesel fuel properties and usage in a compression ignition engine. Fuel. 2016, 163, 80-87. https://doi.org/10.1016/j.fuel.2015.09.048

[20] MIRZAJANZADEH, M., TABATABAEI, M., ARDJMAND, M. et al. A novel soluble nano-catalysts in diesel-biodiesel fuel blends to improve diesel engine performance and reduce exhaust emissions. Fuel. 2015, 139, 374-382. https://doi.org/10.1016/j.fuel.2014.09.008

[21] LENIN, M.A., SWAMINATHAN, M.R., KUMARESAN, G. Performance and emission characteristics of a DI diesel engine with a nanofuel additive. Fuel. 2013, 109, 362-365. https://doi.org/10.1016/j.fuel.2013.03.042

[22] KESKIN, A, METIN, G, ALTIPARMAK, D. Influence of metallic based fuel additives on performance and exhaust emissions of diesel engine. Energy Conversion and Management. 2011, 52, 60-65. https://doi.org/10.1016/j.enconman.2010.06.039

[23] NARINDER, S., BHARJ, R.S. Effect of CNT-emulsified fuel on performance emission and combustion characteristics of four stroke diesel engine. International Journal of Current Engineering and Technology. 2015, 5(1), 477-485. http://inpressco.com/category/ijcet/

[24] DEBNATH, B.K., SAHA, U.K., SAHOO, N. A comprehensive review on the application of emulsions as an alternative fuel for diesel engines. Renewable and Sustainable Energy Reviews. 2015, 42, 196-211. https://doi.org/10.1016/j.rser.2014.10.023

[25] NORHAFANA, M., NOOR, M.M., SHARIF, P.M. et al. A review of the performance and emissions of nano additives in diesel fuelled compression ignition-engines. 1st International Postgraduate Conference on Mechanical Engineering (IPCME2018), IOP Conference Series: Materials Science and Engineering. 2019, 469, 012035. https://doi.org/10.1088/1757-899X/469/1/012035

[26] SHAFII, M.B., DANESHVAR, F., JAHANI, N. et al. Effect of ferrofluid on the performance and emission patterns of a four stroke diesel engine. Advances in Mechanical Engineering. 2011, 3, 1-5. https://doi.org/10.1155/2011/529049

[27] SARVESTANY, S.N., FARZAD, A., BAJESTAN, E.E. et al. Effects of magnetic nanofluid fuel combustion on the per- 
formance and emission characteristics. Journal of Dispersion Science and Technology. 2014, 8, 1745-1750.

https://doi.org/10.1080/01932691.2013.874296

[28] KANNAN, G.R., KARVEMBU, R., ANAND, R. Effect of metal based additive on performance emission characteristics of diesel engine fuelled with biodiesel. Applied Energy. 2011, 88, 3694-3703.

https://doi.org/10.1016/j.apenergy.2011.04.043

[29] SAJITH, V., SOBHAN, C.B., PETERSON, G.P. Experimental investigations on the effects of cerium oxide nanoparticle fuel additives on biodiesel. Advances in Mechanical Engineering. 2010, 36, 1-16. https://doi.org/10.1155/2010/581407

Prof. Janusz T. Cieśliński, DSc., DEng. - Faculty of Mechanical Engineering, Gdańsk University of Technology.

e-mail: jcieslin@pg.gda.pl

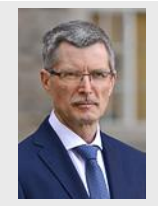

Jan Krzyżak, Eng. - Faculty of Mechanical Engineering, Gdańsk University of Technology.

e-mail: rebusteed@gmail.com
[30] SELVAN, V.A.M., ANAND, R.B., UDAYAKUMAR, M. Effects of cerium oxide nanoparticle addition in diesel and diesel, biodiesel, ethanol blends on the performance and emission characteristics of a CI engine. Journal of Engineering and Applied Sciences. 2009, 4, 1-6.

[31] JAMO, H.U., UMAR, I.D., YUSUF, B. et al.: Enhancement of physical properties of biodiesel extracted from palm oil by the addition $\mathrm{MgO}$ nano particles. International Journal in Physical and Applied Sciences. 2019, 6(5), 1-9.

[32] KEGL, T., KOVAČ, KRALJ A., KEGL B. et al. Nanomaterials as fuel additives in diesel engines: A review of current state, opportunities, and challenges. Progress in Energy and Combustion Science. 2021, 83, 100897. https://doi.org/10.1016/j.pecs.2020.100897

Prof. Jacek Kropiwnicki, DSc., DEng. - Faculty of Mechanical Engineering, Gdańsk University of Technology.

e-mail: jkropiwn@pg.gda.pl

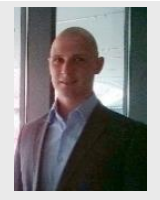

Prof. Zbigniew Kneba, DSc., DEng. - Faculty of Mechanical Engineering, Gdańsk University of Technology.

e-mail: zkneba@pg.gda.pl 